\title{
IDENTIFIKASI NILAI BUDI PEKERTI DALAM LEGENDA MINAK SOPAL (KAJIAN DESKRIPTIF PENGEMBANGAN KARAKTER SISWA BERBASIS KEARIFAN LOKAL)
}

\author{
Zulva Zannatin Alia \\ zannatinzulva@gmail.com
}

\begin{abstract}
Abstrak
Penelitian ini bertujuan untuk mengidentifikasi dan mendeskripsikan mengenai nilainilai budi pekerti dalam Legenda Minak Sopal. Penelitian ini menggunakan metode kualitatif dengan tipe riset deskriptif. Hasil analisis menunjukkan bahwa terdapat 11 (sebelas) nilai budi pekerti dalam Legenda Minak Sopal yaitu nilai kesederhanaan, nilai cinta ilmu, tanggung jawab, welas asih, bijaksana, berani, gigih, sabar, kepemimpinan, optimis, dan religius. Nilai-nilai tersebut terangkum menjadi tiga unsur karakter menurut konsepsi Memayu Hayuning Bawana, sehingga menghasilkan temuan penelitian berupa tiga unsur karakter; yaitu bawana alit, bawana agung, dan bawana langgeng. Bawana Alit diartikan sebagai sikap, perilaku dan karakter yang ditujukan untuk individu, pribadi, dan keluarga. Terdapat nilai budi pekerti dalam bawana alit yaitu cinta ilmu, berani, gigih, sabar, optimis, dan sederhana. Sementara itu Bawana Agung diartikan sebagai sikap, perilaku, dan karakter yang ditujukan untuk masyarakat, bangsa, negara dan dunia international atau global, terdiri dari nilai budi pekerti welas asih, berjiwa pemimpin, tanggung jawab, dan bijaksana. Konsepsi karakter terakhir adalah Bawana Langgeng, yaitu sikap, perilaku, dan karakter yang ditujukan untuk alam akhirat, terdiri dari nilai religius.
\end{abstract}

Kata Kunci : Legenda Minak Sopal, Karakter, Siswa.

\section{PENDAHULUAN}

Legenda atau cerita rakyat merupakan akar budaya yang bisa menjadi pijakan remaja dalam mengembangkan karakter melalui cerita-cerita yang disampaikan. Dalam sebuah kisah legenda ditemukan tema dan makna simbolik tentang budi pekerti dan sosial. Ia bersifat fiktif dan anonim, tetapi membawa ajaran dan pesan-pesan tertentu. Ajaran dan pesan itu terselip di balik karakter tokohtokohnya, baik ketika tokoh tersebut menghadapi masalah dan cara mengatasinya serta bagaimana memperjuangkan cita-citanya.

Karakter dalam cerita biasanya dimaksudkan sebagai suatu saran yang berhubungan dengan ajaran karakter yang bersifat praktis, yang dapat diambil lewat cerita yang bersangkutan oleh pembaca (Nurgiyantoro, 2010). Oleh karena itu, karakter dalam suatu cerita merupakan petunjuk yang secara sengaja diberikan oleh pengarang mengenai berbagai hal yang berhubungan dengan masalah kehidupan, seperti sikap, tingkah laku dan etika pergaulan. Melalui cerita, 
sikap, dan tingkah laku tokoh-tokoh itulah pembaca diharapkan dapat mengambil hikmah dan meniru karakter positif dalam cerita. Karakter positif dalam cerita rakyat dapat dipandang sebagai amanat, pesan atau message. Hikmah yang diperoleh pembaca lewat cerita rakyat selalu dalam pengertian yang baik. Karakter baik dan buruk dalam cerita sengaja ditampilkan supaya pembaca dapat mengambil hikmah dari cerita tersebut serta tidak mencontoh perilaku yang buruk sehingga pembaca termotivasi untuk mencontoh karakter baik yang diperankan oleh tokoh dalam cerita. Pemahaman atas suatu cerita rakyat hingga mendapatkan hikmah tersebut merupakan bagian dari penanaman nilai budi pekerti dan pembentukan karakter.

Salah satu Legenda yang sarat dengan nilai budi pekerti adalah legenda Minak Sopal. Cerita ini berasal dari Desa Ngantru, Kabupaten Trenggalek, Jawa Timur. Desa Ngantru terletak sekitar 400 meter arah barat laut dari Pendopo Kabupaten Trenggalek. Mayoritas masyarakat Desa Ngantru memiliki keyakinan memeluk agama Islam.

Penelusuran mengenai nilai-nilai karakter dalam cerita rakyat Minak Sopal terungkap melalui penokohan yang terdapat dalam cerita rakyat tersebut. Salah satu penggalan ceritanya adalah seperti yang diungkapkan budayawan SE sebagai berikut.

"Ketika itu ada utusan dari yang mau mengislamkan daerah Trenggalek, bernama Ki Srabah atau dinamakan Minak Srabah.Dulu, entah itu benar atau tidak ya namanya dongeng ya, lek di paido yo ora mengeng, itu bisa menjelma menjadi bajul putih yang membuat pesantren di daerah dukuh Bagong. Ketika itu bersamaan juga Majapahit waktu itu masih Hindu Budha belum Islam semua.Punya putri yang sebenarnya cantik, karena sakit berbau tidak enak sehingga dinamakan Endang Roro Amis.Ya mungkin itu dinamakan pralampito ya. Kenapa kok dinamakan roro amis? Mungkin kok bukan amis baunya ndak enak, tidak, tapi tingkah lakunya yang kurang baik." (WW/SE/13-01-2018)

Legenda Minak Sopal mengandung makna-makna yang tersirat melalui simbol-simbol. Dalam cuplikan cerita tersebut, salah satu simbolisasi dalam penokohan adalah nama Roro Amiswati. Amis yang dimaksud disini adalah bukan tentang bau atau rupa yang buruk, tapi dapat dimaknai dengan perilaku dan perangai yang buruk. Dalam cuplikan yang lain disebutkan,

Kamu siapa? Saya orang kecil saja, saya mencoba kalau lah bisa.Coba sembuhkan.Saya ingin menyembuhkan dari kakinya. Kemudian minak srabah menjilati kaki roro amis. Kenapa kok jilat? Itu kan symbol ya, jadi menjilat itu kan lidah, ucapan, dari kakinya kenapa? Tingkah laku perbuatan untuk berjalan.Sembuh karena kata-kata yang indah, lembut, pitutur, andhap ashor.Sebelum mati harus berarti. (WW/SE/13-01-2018)

Penggalan cerita tersebut mengisahkan bahwa Minak Sraba menyembuhkan Roro Amiswati dengan cara menjilati kakinya, dapat dimaknai bahwa menjilat berarti lidah atau tutur kata. Perangai buruk yang dimiliki Amiswati disembuhkan dengan cara 
memberikan pitutur-pitutur yang baik sehingga dapat sembuh.

Selain dari segi penokohan, dari alur cerita terdapat makna-makna yang dapat mengungkap nilai-nilai budi pekerti dalam legenda Minak Sopal. Berdasarkan sejarahnya, Minak Sopal adalah cerita tentang penyebaran Agama Islam di tanah Trenggalek yang dilakukan oleh utusan dari Demak Bintoro. Oleh karena itu, cerita rakyat Minak Sopal sangat sarat dengan nilai religius, karena sedari awal cerita ini membawa semangat juang Minak Sopal untuk menyebarkan agama Islam di Trenggalek yang saat itu masyarakatnya masih memeluk agama Hindu dan Budha.

Nilai religius terlihat pada salah satu penggalan cerita berikut,

"Minak Sopal ingin belajar agama Islam dan bertemu ayahnya Minak Sraba, kemudian ia bertanya ke ibunya.Roro Amiswati kemudian memberitahu Minak Sopal perihal ayahnya yang merupakan penjelmaan Bajul Putih yang saat ini tinggal di daerah Bagong." (PBT/2016/309/Pa5)

Kutipan cerita ini mengisahkan tentang keinginan Minak Sopal untuk belajar Agama Islam kepada ayahnya. Ia kemudian berinisiatif untuk menanyakan hal tersebut kepada ibunya mengenai keberadaan ayahnya. Berdasarkan cerita tersebut didapatkan makna nilai religius dari Minak Sopal, bahwa keyakinan Minak Sopal akan kebenaran agama Islam membawa ia untuk mencari tahu serta menemui ayahnya Minak Sraba.

Nilai-nilai budi pekerti dalam Legenda Minak Sopal sudah seharusnya menjadi pijakan siswa- siswa Trenggalek dalam membentuk dan mengembangkan karakter yang bertanggungjawab, pantang menyerah, dan sederhana seperti yang telah dicontohkan. Namun, fakta di lapangan membuktikan bahwa masih banyak siswa-siswa yang tidak memiliki karakter tersebut.

Berdasarkan wawancara dengan konselor di SMK Gajah Mada Trenggalek, ditemukan bahwa:

"Siswa seperti mengalami masamasa krisis karakter.Padahal upaya regulasi seperti Perpres tentang Penguatan Karakter juga telah dikeluarkan, tapi sepertinya belum efektif.Masalah yang kerap kali timbul mulai dari siswa yang tidak menghargai guru, membolos, hingga ada siswa yang menghamili dan hamil di luar nikah." (WW/DD/2712-2018)

Argumen konselor tentang peliknya kebimbangan siswa tentang karakternya membawa mereka pada situasi yang bernama krisis karakter. Siswa mengalami degradasi moral, dengan menampakkan perilakuperilaku yang bertentangan dengan nilai dan norma sosial di masyarakat. Kebingungan karakter yang direpresentasikan remaja melalui perilaku yang bertentangan dengan nilai-nilai diutarakan pula oleh siswa berdasarkan petikan wawancara sebagai berikut.

"Paling sering ya kalau rame gitu di kelas Bu, kadang gurunya ngomong didepan sama temen-temen gak didengerin. Terus kalau ada tugas itu gak mau ngerjakan sendiri. Selalu minta contohan (contekan) temennya. Lek gak dikasih malah dicap pelit Bu." (WW/ZK/28-122018) 
Pernyataan di atas menunjukkan beberapa perilaku siswa yang bertentangan dengan nilai-nilai, yaitu perilaku tidak menghargai guru (respect), dan tidak mau bertanggung jawab atas tugas yang telah diberikan guru. Karakter-karakter seperti respect dan tanggung jawab di atas padahal penting untuk dimiliki siswa saat ini sebagai bagian dari generasi $\mathrm{Z}$ untuk mewujudkan Indonesia dengan generasi emas di tahun 2045.

Pentingnya karakter respect dan tanggung jawab juga disebutkan oleh Kemendikbud yang telah mengidentifikasi 18 nilai karakter yang bersumber dari agama, Pancasila, budaya dan Tujuan Pendidikan Nasional, yaitu religius, jujur, toleransi, disiplin, kerja keras, kreatif, mandiri, demokratis, rasa ingin tahu, semangat kebangsaan, cinta tanah air, menghargai prestasi, bersahabat/komunikatif, cinta damai, gemar membaca, peduli lingkungan, peduli sosial, dan tanggung jawab (Pusat Kurikulum dan Perbukuan, 2011).

Perilaku-perilaku yang seolah pelanggaran ringan tersebut justru adalah persoalan karakter serius yang harus menjadi tanggung jawab kita bersama. Konselor memiliki peran untuk mengembangkan karakter baik yang dimiliki siswa. Siswa yang memiliki karakter baik akan dapat mengetahui hal baik, merasa yang baik, dan akan melakukan hal baik. Hal ini sejalan dengan pendapat Lickona (1991), bahwa karakter adalah keterkaitan antara pengetahuan moral (moral knowing), perasaan moral (moral feeling), dan tingkah laku moral (moral action). Secara menyeluruh dapat dimaknai bahwa siswa yang berkarakter baik, akan dapat mengetahui hal yang baik, memiliki perasaan terhadap hal yang baik, serta akan melakukan hal baik. Aplikasi dalam kehidupan siswa, ketiga komponen dari karakter akan membentuk seseorang memiliki kebiasaan yang baik dalam berpikir, kemauan dan tindakan yang baik dalam berinteraksi dengan diri dan orang lain.

Berdasarkan fakta-fakta tersebut, pengembangan karakter sangat diperlukan agar siswa mampu mengoptimalkan potensi yang dimilikinya sehingga dapat mengarah pada budaya hidup produktif. Pengembangan karakter dapat dilakukan melalui adopsi karakter dari hasil telaah atau identifikasi nilai-nilai budaya luhur bangsa salah satunya berasal dari legenda atau cerita rakyat.

Penelitian nilai karakter yang berasal dari cerita bukan hal yang baru terjadi. Salah satu penelitian dengan basis cerita untuk menggali nilai-nilai karakter adalah hasil penelitian Gusria (2015) dengan judul penelitiannya Karakter Individu Mandiri dalam Karya Buya Hamka dan Kontribusinya bagi Bimbingan Berbasis Budaya, mengungkapkan bahwa Novel Karya Buya Hamka memiliki representasi nilai karakter individu mandiri masyarakat Minangkabau yang bisa diadaptasi dalam Bimbingan dan Konseling. Karya-karya Buya Hamka tersebut memiliki nilai-nilai yang dapat ditiru dan dijadikan bahan bimbingan untuk menguatkan karakter individu mandiri.

Berdasarkan penjabaran data dan kajian yang telah disampaikan, maka calon peneliti memiliki gagasan tentang penelitian. Gagasan tersebut, bahwa degradasi moral saat ini melanda peserta didik yang ditandai 
dengan perilaku yang tidak sesuai nilai dan norma yang berlaku, maka perlu adanya penguatan karakter melalui adopsi nilai-nilai luhur yang mencerminkan kepribadian bangsa. Nilai-nilai tersebut didapat dari hasil identifikasi Legenda atau cerita rakyat. Legenda yang dipilih adalah Minak Sopal dengan alasan bahwa cerita tersebut merepresentasikan cerita asalusul daerah Trenggalek serta kaya akan pesan moral dan nilai budi pekerti sehingga dapat dijadikan rujukan dalam mengembangkan karakter khas masyarakat Trenggalek kepada siswa. Berdasarkan penjabaran tersebut, maka dirasa perlu adanya upaya pengkajian nilai-nilai budi pekerti yang dapat diadopsi dari legenda Minak Sopal untuk mengembangkan karakter siswa.

Hasil kajian teoritis ini nantinya dapat digunakan sebagai rujukan dan bahan penelitian selanjutnya dalam tataran praktis bimbingan dan konseling untuk mengembangkan karakter siswa.

\section{METODE PENELITIAN}

Penelitian ini menggunakan pendekatan kualitatif dengan tipe penelitian deskriptif. Sumber data primer didapatkan melalui dokumen tertulis berupa buku teks tentang cerita rakyat Minak Sopal yaitu Ki Ageng Minak Sopal (Soeyono, 2018), Sejarah Masjid Agung (Wilis, 2005) dan Peta Budaya Trenggalek (Soyomukti, N., 2016). Pengecekan keabsahan data dilakukan dengan kegiatan triangulasi data. Bentuk dari penelitian ini adalah mendeskripsikan, menganalisis, serta menafsirkan nilai karakter dalam cerita rakyat Minak Sopal.

\section{HASIL DAN PEMBAHASAN}

Proses analisis data telah menghasilkan temuan penelitian berupa sebelas nilai budi pekerti dalam Legenda Minak Sopal yaitu nilai kesederhanaan, nilai cinta ilmu, tanggung jawab, welas asih, bijaksana, berani, gigih, sabar, kepemimpinan, optimis, dan religius. Nilai-nilai ini nantinya dibagi menjadi tiga unsur karakter berdasarkan konsep Метауи Hayuning Bawana yaitu Bawana Alit, Bawana Agung, dan Bawana Langgeng. Setelah ditemukan unsurunsur karakter kemudian akan dikaji lebih lanjut dengan berdasarkan teori keilmuan terkait karakter (theorizing) sehingga ditemukan kesatuan horizon temuan akhir penelitian.

\section{Legenda Minak Sopal dan Kebangkitan Eksistensi Kearifan Lokal}

Beberapa akademisi mempercayai bahwa praktik lokal memainkan peran yang positif dalam kehidupan masyarakat. Pendapat berbeda disampaikan oleh Edgerton (2011), ia menganggap bahwa manusia tidak selalu bijaksana, dan masyarakat serta budaya yang mereka ciptakan bukan merupakan mekanisme adaptif yang ideal, yang dirancang secara sempurna untuk memenuhi kebutuhan manusia. Sehingga, keliru jika terus menganggap bahwa apabila sebuah populasi memegang kepercayaan atau praktik tradisional selama bertahuntahun, maka kepercayaan dan praktik itu pastilah memainkan peranan penting dalam kehidupan mereka. Kepercayaan dan praktik tradisional bisa berguna, bisa juga berfungsi sebagai mekanisme adaptif yang penting, tetapi juga bisa tidak efisien, berbahaya, bahkan membawa maut. 
Tampaknya, kita dapat melihat potongan kesesuaian antara praktik lokal yang terjadi di Trenggalek dengan asumsi Edgerton (2011) di atas. Pada mulanya, praktik lokal bersih dam bagong masih diwarnai oleh kepercayaan mistis sehingga ritualritual pelaksanaannya seolah melenceng dari ajaran agama. Namun saat ini, peningkatan secara signifikan terjadi di beberapa aspek perayaan upacara bersih dam bagong. Kegiatan bukan lagi bersifat persembahan sesuatu dengan ritual yang bersifat klenik, namun telah berganti diisi dengan kegiatan-kegiatan keagamaan. Pada pembahasan saat ini tentu tidak berfokus pada praktik lokal bersih dam bagong, namun bertolak pada kejadian yang mendasari terjadinya praktik lokal tersebut yaitu kisah legenda Minak Sopal.

Sebagai sosok yang religius, Minak Sopal mencontohkan bagaimana menjadi pribadi yang taat kepada ajaran agamanya. Oleh karena itu penting untuk memaknai kembali cerita dalam legenda Minak Sopal tersebut untuk memahami nilai-nilai yang terkandung serta menginternalisasikannya dalam kehidupan sehari-hari, kaitannya untuk mengembangkan karakter. Memahami bahwa dengan memaknai sebuah cerita rakyat sebagai kearifan lokal suatu daerah untuk menjadi alternatif pengembangan potensi terkait sikap, perilaku, dan karakter, dalam menjalani kehidupan bukan hal sulit. Nilai-nilai dalam cerita rakyat yang berwujud nilai-nilai luhur budaya bangsa sejalan dengan nilai-nilai yang menjadi pengharapan terbentuknya masyarakat dengan karakter ideal.

Mappiare (2017) menyebutkan bahwa karakter ideal berdasarkan budaya bangsa adalah yang luwes, serasi, seimbang, selaras, antara unsurunsur dari karakter yang terangkum dalam pandangan hidup yang disebut PANTEs yaitu (1) Pola pikir utuh yaitu pemikiran mengenai pribadikemanusiaan-lingkungan, (2) Aksi posisional utuh yaitu kesiapan bertindak yang praktis, idealis, dan realis, (3) Norma luwes utuh, yaitu mempertimbangkan standar-standar individualism, kolektivisme, universalisme, (4) Tenggang rasa utuh, yaitu mempertimbangkan rasa etnis, nasionalis, internasionalis, serta (5) Sistem keyakinan/nilai utuh, yaitu berorientasi materialis, sosialis, religius.

Artiya justru dengan kembali kepada nilai-nilai luhur budaya bangsa, kemajuan peradaban manusia yang ditandai dengan terwujudnya karakter ideal pada setiap diri individu adalah sebuah keniscayaan. Pada dasarnya, telah menjadi tugas akademisi untuk membuktikan bahwa sesuatu hal yang diyakini masyarakat tidak memiliki pengaruh besar, justru adalah suatu asset budaya yang memiliki pengaruh dan bisa dipertanggungjawabkan secara ilmiah. Sebagai contoh adalah legenda Minak Sopal yang hingga kini ceritanya, walaupun dengan berbagai versi, tetap hidup di masyarakat. Cerita dalam legenda tersebut mengandung nilai-nilai budi pekerti yang mewakili karakteristik masyarakat Trenggalek. Nilai kesederhanaan misalnya, Trenggalek dengan karakteristik wilayah yang dikelilingi pegunungan dan lautan, memiliki masyarakat yang tidak hanya tinggal di daratan dan perkotaan, namun juga tersebar di daerah pegunungan, pesisir, dan pedesaan lainnya, hingga kini masih menjunjung tinggi nilai kesederhanaan dalam kehidupan sehari-hari. Apabila 
mengacu pada kerangka ekokultural dari Berry (2002) yang menyatakan bahwa tipologi geografis mempengaruhi cara bertahan hidup, dan perbedaan-perbedaan regional dalam perilaku bertahan hidup dasar ini pada akhirnya menimbulkan banyak ritual, adat istiadat, dan norma-norma yang berkembang di dalam kelompok orang tersebut, maka barangkali kita bisa berasumsi bahwa nilai kesederhanaan yang ditampakkan masyarakat Trenggalek adalah dipengaruhi oleh kondisi geografis.

Namun, asumsi ini dipatahkan oleh hasil penelitian melalui wawancara terhadap juru kunci makam Minak Sopal, meskipun bertempat tinggal di daerah perkotaan (kawasan makam Minak Sopal berada ditengah kota), namun perilaku dan sikap informan menampakkan nilai kesederhanaan dengan baik. Informan tidak menjadi pribadi yang individualistik layaknya masyarakat perkotaan. Ia tetap menghabiskan hariharinya dengan berutinitas sebagai petani, begitu juga masyarakat di sekitar kawasan makam yang lain. Sebagai juru kunci makam Minak Sopal, ia paham betul bagaimana seluk beluk cerita legenda tersebut.Ia menerapkan dengan baik nilai kesederhanaan yang dicontohkan Minak Sopal. Hal ini menggambarkan bahwa nilai-nilai dalam sebuah legenda yang telah terjadi ratusan tahun yang lalu, apabila diyakini dan diinternalisasikan dalam kehidupan sehari-hari dengan baik maka akan membentuk dan menjadi representasi karakter masyarakat tersebut. Nilainilai kearifan lokal bukanlah nilai usang yang ketinggalan zaman sehingga ditinggalkan, tetapi dapat bersinergi dengan nilai-nilai universal dan nilai-nilai modern yang dibawa arus globalisasi (Nugroho dan Elviandri, 2018). Akar-akar budaya bangsa merupakan basis membangun karakter kemanusiaan guna membentuk kepribadian bangsa yang adiluhung. Kemerdekaan berakar pada karakter kemanusiaan yang membentuk kepribadian bangsa berbasis nilai-nilai budaya adiluhung para leluhur (Syarief, 2015).

Sungguh disayangkan, kondisi ideal di masyarakat yang mampu mengejawantahkan nilai-nilai dalam legenda Minak Sopal ke dalam kehidupan sehari-hari tersebut tidak diikuti oleh peserta didik di lingkungan sekolah. Fenomena degradasi moral serta krisis karakter peserta didik, telah dijelaskan secara gamblang di latar belakang, sehingga membutuhkan upaya yang tepat untuk mencegah dan memperbaikinya. Bimbingan dan Konseling memiliki peranan dan tanggung jawab yang besar untuk mengembangkan karakter peserta didik menuju manusia ideal seutuhnya.

\section{Memayu Hayuning Bawana: Internalisasi Nilai dan Keseimbangan Karakter}

Salah satu upaya dilakukan untuk menguatkan karakter siswa adalah melalui internalisasi nilai-nilai budaya yang terejewantahkan melalui tradisi lisan sebagai bentuk warisan kearifan lokal suatu daerah. Nilai karakter bangsa salah satunya mewujud sejak lama dalam tradisi lisan Nusantara berupa kisah legenda atau cerita rakyat (Indiarti, 2017). Sebagai warisan budaya, kisah legenda perlu dilestarikan, diolah,dan dijadikan salah satu media penting dalam internalisasi nilai-nilai luhur bangsa. Jauh lebih penting dari pemahaman adalah 
penghayatan dan pengamalan yang kongkret dalam kehidupan sehari-hari di masyarakat. Pengetahuan, perasaan, dan perilaku merupakan bagian integral dari penerapan pendidikan karakter bangsa yang seharusnya dilaksanakan secara harmoni. Dengan keharmonisan ketiga aspek tersebut maka bangsa dan negara kita akan memiliki karakter yang tangguh dalam menghadapi berbagai tantangan zaman.

Legenda Minak Sopal memiliki 11 (sebelas) nilai yang telah teridentifikasi mampu untuk mengembangkan karakter. Nilai - nilai budi pekerti ini kemudian dikategorisasikan berdasarkan konsep karakter dalam falsafah Jawa Memayu Hayuning Bawana, sehingga menghasilkan temuan penelitian berupa tiga unsur karakter; yaitu bawana alit, bawana agung, dan bawana langgeng. Bawana Alit diartikan sebagai sikap, perilaku dan karakter yang ditujukan untuk individu, pribadi, dan keluarga. Terdapat nilai budi pekerti dalam bawana alit yaitu cinta ilmu, berani, gigih, sabar, optimis, dan sederhana. Sementara itu Bawana Agung diartikan sebagai sikap, perilaku, dan karakter yang ditujukan untuk masyarakat, bangsa, negara dan dunia international atau global, terdiri dari nilai budi pekerti welas asih, berjiwa pemimpin, tanggung jawab, dan bijaksana. Konsepsi karakter terakhir adalah Bawana Langgeng, yaitu sikap, perilaku, dan karakter yang ditujukan untuk alam akhirat, terdiri dari nilai religius.

Ketiga unsur tersebut adalah perwujudan dari "sustainable development" sebagai keselarasan vertikal dan horizontal yang tak terputus. Artinya adalah falsafah hidup yang secara vertikal mengatur tata hubungan antara manusia dengan Sang Pencipta, sedangkan secara horizontal, mengatur tata hubungan antara manusia dengan manusia, manusia dengan alam tempatnya hidup, serta hubungan antara manusia dengan makhluk hidup lain, di antaranya hewan dan tumbuhan.

Masyarakat Jawa mempunyai konsep secara spiritual dalam menjaga harmonisasi hubungan antara Tuhan, alam semesta dan manusia dalam konsep "Memayu Hayuning Bawana". Konsep ini memiliki makna bagaimana untuk dapat memakmurkan alam semesta, mempercantik keindahan alam semesta atau menjaga alam semesta dengan baik dengan memadukan konsep fisik dan spiritual dalam kehidupan alam semesta. Konsep memayu hayuning bawana merupakan filosofi yang mengandung dimensi karakter secara komprehensif juga sebagai filsafat spiritual masyarakat Jawa dalam menjaga aktualisasi dalam hukum pengelolaan sumber daya alam agar harmonisasi alam semesta tetap terjaga kelestarian dan keberlajutan yang selalu menekankan keselarasan manusia dengan manusia, manusia dengan alam, dan manusia dengan Tuhan dalam melaksanakan hidup dan kehidupan (Nugroho dan Elviandri, 2018).

Sehingga dapat diartikan bahwa konsep Memayu Hayuning Bawana mengajarkan masyarakat untuk bersikap dan berperilaku yang selalu mengutamakan harmoni, keselarasan, keserasian dan keseimbangan hubungan antara manusia dengan alam, manusia dengan manusia dan manusia dengan Tuhan dalam melaksanakan hidup dan kehidupan.

Keseimbangan dan keselarasan hidup juga dikenal dalam Islam dengan sebutan Rahmatan lil 'alamin. Islam 
adalah rahmat bagi seluruh alam. Ia tidak hanya mengatur hubungan dengan Tuhan (hablumminallah), namun juga hubungan dengan manusia (hablumminannas), dan hubungan dengan alam (hablumminalalam) (QS. Al-Baqarah [2]: 21-22). Tatanan ideal dalam Al-Qur'an perlu untuk ditindaklanjuti dalam tataran empiris. Arfiyah (2014) dalam disertasinya menyebutkan bahwa manusia memiliki potensi karakter maskulin dan feminism. Keseimbangan antara kedua karakter tersebut akan mendukung terciptanya keharmonisan antara keseluruhan relasi. Keseimbangan karakter yang positif merupakan suatu hal yang niscaya bagi setiap manusia yang hendak memiliki kesempurnaan karakter dalam dirinya. Keseimbangan karakter ini akan menimbulkan keharmonisan interaksi antara diri sendiri, dengan sesama manusia, alam raya dan Tuhan. Keharmonisan hubungan vertikal dan horizontal akan menjadikan manusia sukses dalam hidup, baik sebagai makhluk individual, makhluk sosial, bahkan makhluk spiritual.

Keseimbangan dan keselarasan karakter juga disebutkan oleh Mappiare (2017) tentang konsepsi karakter dalam Konseling KIPAS yang menekankan pada keseimbangan dan keselarasan dari unsur-unsur karakter untuk mencapai manusia ideal, terangkum dalam pandangan hidup yang disebut PANTEs yaitu (1) Pola pikir utuh yaitu pemikiran mengenai pribadikemanusiaan-lingkungan, (2) Aksi posisional utuh yaitu kesiapan bertindak yang praktis, idealis, dan realis, (3) Norma luwes utuh, yaitu mempertimbangkan standar-standar individualism, kolektivisme, universalisme, (4) Tenggang rasa utuh, yaitu mempertimbangkan rasa etnis, nasionalis, internasionalis, serta (5) Sistem keyakinan/nilai utuh, yaitu berorientasi materialis, sosialis, religius. Artinya terdapat unsur-unsur karakter yang harus dipenuhi untuk menjadi manusia ideal, unsur-unsur tersebut tidak hanya berupa unsur horizontal, namun juga unsur vertical yang disebut sistem keyakinan utuh, berorientasi religius. Keseimbangan antara unsur-unsur karakter ini akan membawa menuju manusia ideal seutuhnya.

Peterson \& Seligman (2004) juga mengklasifikasikan karakter menjadi beberapa bagian hirearki.Klasifikasi tersebut tidak hanya berupa skema horizontal namun juga vertical. Terdapat enamvirtues (inti dari nilai moral) dan dua puluh empat character strengths (pengejawantahan dari virtues) semuanya mencakup nilainilai karakter yang berkaitan dengan hubungan sesama manusia serta hubungan dengan Tuhan sebagai keyakinannya (religious).

Kementerian Pendidikan Nasional di tahun 2010 juga telah membuat identifikasi nilai-nilai pembentuk karakter bangsa. Dalam rangka lebih memperkuat pelaksanaan pendidikan karakter pada satuan pendidikan telah diidentifikasi 18 nilai yang bersumber dari agama, Pancasila, budaya dan Tujuan Pendidikan Nasional, yaitu religius, jujur, toleransi, disiplin, kerja keras, kreatif, mandiri, demokratis, rasa ingin tahu, semangat kebangsaan, cinta tanah air, menghargai prestasi, bersahabat/komunikatif, cinta damai, gemar membaca, peduli lingkungan, peduli sosial, dan tanggung jawab (Pusat Kurikulum dan Perbukuan, 2011: 8). 
Nilai-nilai tersebut pada tahun 2017 kemudian dikristalisasi menjadi 5 (lima) nilai utama dalam Gerakan Penguatan Pendidikan Karakter (GPPK), yaitu nilai religius, nasionalis, mandiri, gotong royong, dan integritas. Nilai-nilai utama tersebut memiliki jabaran-jabaran subnilai yang sesuai dengan kriteria nilai utama.Berdasarkan klasifikasi tersebut, identifikasi nilai karakter oleh Kemendikbud tidak hanya mengacu kepada hubungan dengan manusia, namun juga hubungan dengan Tuhan dan alam.

Masyarakat Trenggalek yang identik dengan budaya Jawa memegang teguh falsafah-falsafah para leluhur. Memayu hayuning bawana adalah sebuah falsafah sekaligus laku (pekerti) masyarakat Jawa. Terdapat tiga strategi pokok untuk mencapai karakter memayu hayuning bawana pada tataran kehidupan yaitu (1) strategi mengolah diri pribadi, olah batin, dan olah rasa, (2) strategi interaksi sosial, (3) strategi berinteraksi dengan Tuhan (Endraswara, 2016).

Sejalan dengan ketiga strategi tersebut, Kementerian Pendidikan (2017) juga mengungkapkan strategi yang sama untuk mencapai penguatan karakter, yaitu dengan gerakan pendidikan di sekolah untuk memperkuat karakter melalui proses pembentukan, transformasi, transmisi, dan pengembangan potensi peserta didik dengan cara harmonisasi olah hati (etik dan spiritual), olah rasa (estetik), olah pikir (literasi dan numerasi), dan olah raga (kinestetik) sesuai falsafah hidup Pancasila. Untuk itu diperlukan dukungan pelibatan publik dan kerja sama antara sekolah, keluarga, dan masyarakat.

\section{Keterkaitan Nilai Karakter Minak Sopal dengan Bidang Layanan Bimbingan dan Konseling}

Dalam pelayanan bimbingan dan konseling, peranan guru bimbingan dan konseling/konselor tidak terfokus hanya membantu peserta didik/konseli yang bermasalah, melainkan membantu semua peserta didik/konseli dalam pengembangan ragam potensi, meliputi pengembangan aspek belajar, karier, pribadi, dan sosial. Bimbingan dan konseling di sekolah dilaksanakan secara kolaboratif dengan para guru mata pelajaran, tenaga kependidikan, maupun orang tua dan pemangku kepentingan lainnya. Keutuhan layanan bimbingan dan konseling diwujudkan dalam landasan filosofis bimbingan dan konseling yang memandirikan, berorientasi perkembangan, dengan komponen-komponen program yang mencakup layanan dasar, layanan responsif, layanan peminatan dan perencanaan individual, dan dukungan sistem.

Keterkaitan karakter dengan tema konseling yang lain ditujukan agar bisa menemukan bagian-bagian penting di dalam tema lain konseling yang bisa dikorelasikan dengan karakter. Terdapat nilai budi pekerti dalam bawana alit yaitu cinta ilmu, berani, gigih, sabar, optimis, dan sederhana. Sementara itu bawana agung diartikan sebagai sikap, perilaku, dan karakter yang ditujukan untuk masyarakat, bangsa, negara dan dunia international atau global, terdiri dari nilai budi pekerti welas asih, berjiwa pemimpin, tanggung jawab, dan bijaksana. Konsepsi karakter terakhir adalah Bawana Langgeng, yaitu sikap, perilaku, dan karakter yang ditujukan untuk alam akhirat, terdiri dari nilai religius. Jika mengacu pada temuan 
penelitian, maka karakter tersebut yang akan dihubungkan dengan tema lain konseling.

Legenda Minak Sopal memiliki sebelas nilai budi pekerti yang dapat digunakan untuk mengembangkan karakter, kesebelas nilai itu dapat masuk ke wilayah bidang bimbingan pribadi dan sosial. Nilai-nilai dalam legenda Minak Sopal dapat diadopsi untuk mengembangkan pribadi peserta didik yang berkarakter. Sementara itu terkait tema sosial atau "kehidupan sosial" atau "kecakapan hidup sosial" peserta didik mencakup bidang luas sebagai konsekuensi dari hakikat manusia sosial. Dalam kehidupan sosial setiap orang berpeluang mengekspresikan diri dalam aksi dan komunikasi atau interaksi yang favoribel. Legenda Minak Sopal memiliki nilai - nilai yang banyak menyangkut dengan tema sosial. Cerita dalam legenda Minak Sopal penuh dengan hikmah yang dapat diambil untuk menjalani kehidupan sosial yang baik. Nilai welas asih dan bijaksana misalnya, patut dijadikan pijakan dalam berinteraksi dan membangun hubungan yang baik dengan orang lain. Minak Sopal mencontohkan sikap hidup welas asih dan bijaksana dengan sangat baik. Setiap keputusan-keputusan yang ia buat adalah berdasarkan kemaslahatan dan kepentingan orang banyak. Hal ini terkait dalam konsepsi kecakapan sosial menurut Mappiare (2017), yaitu berkaitan dengan Andalan Diri; menurut pada kepentingan diri dan orang lain, atau keberanian menempuh resiko logis dan tanggung jawab sosial

Selanjutnya bidang bimbingan karir, adalah tema kajian konseling yang secara pasti menyertakan kajian kepribadian. Pada satu sisi, kajian menyangkut pemikiran dan perencanaan masa depan, dan pada lain sisi adalah latihan-latihan identifikasi dan klarifikasi ciri-ciri pribadi, latihanlatihan pembuatan pilihan dan pengambilan keputusan pekerjaan. Kajian tentang nilai budi pekerti dalam Minak Sopal menghasilkan beberapa identifikasi nilai yang dapat dikaitkan dengan tema pekerjaan atau karir, yaitu nilai tanggung jawab dan kepemimpinan. Minak Sopal adalah pribadi yang bertanggung jawab atas setiap tugas dan pekerjaan yang dibebankan. Keberhasilan pembangunan bendungan tidak lepas dari karakter tanggung jawab yang dimilikinya. Minak Sopal juga sosok pemimpin. Di bawah kepemimpinannya, agama Islam menyebar tidak hanya di Trenggalek namun hingga ke pesisir selatan Jawa. Tanggung jawab dan kepemimpinan adalah karakter yang harus dimiliki siswa untuk menunjang keberhasilan perencanaan pekerjaan atau karir peserta didik di waktu yang akan datang.

Bidang selanjutnya adalah tentang Bimbingan Belajar (akademik). Akademik sebagai tema pembahasan dalam konseling meliputi banyak dimensi belajar (studi) konseli, terutama tujuan dan strategi belajar, potensi dan realisasi, pendukung dan penghambat, dan banyak lagi faktor yang terkait belajar. Nilai dalam legenda Minak Sopal yang bisa dikaitkan dengan belajar adalah nilai cinta ilmu. Minak Sopal adalah pribadi yang memiliki ketertarikan dengan ilmu. Ia menghabiskan masa mudanya untuk menuntut ilmu agama dan pemerintahan. Setelah selesai, ia kemudian mengaplikasikan ilmu yang didapat dalam masyarakat. Nilai cinta ilmu ini dapat menjadi faktor 
pendukung siswa terkait keberhasilannya dalam proses belajar (akademik).

Demikian adalah keterkaitan nilai - nilai karakter Minak Sopal dengan kajian bidang bimbingan dan konseling yaitu bimbingan pribadi dan social, bimbingan karir, dan bimbingan belajar.

\section{KESIMPULAN}

Terdapat sebelas nilai budi pekerti yang teridentifikasi dalam legenda Minak Sopal, nilai-nilai tersebut adalah kesederhanaan, cinta ilmu, tanggung jawab, welas asih, religius, gigih, berani, bijaksana, sabar, berjiwa pemimpin, dan optimis.

Nilai-nilai tersebut terangkum menjadi tiga unsur karakter menurut konsepsi karakter dalam falsafah Jawa Memayu Hayuning Bawana. Unsurunsur tersebut yaitu bawana alit, bawana agung, bawana langgeng.

Bawana alit dimaknai sebagai sikap, perilaku dan karakter yang ditujukan untuk individu, pribadi, dan keluarga. Terdiri dari nilai cinta ilmu, berani, gigih, sabar, optimis, dan sederhana Bawana agung dimaknai sebagai sikap, perilaku, dan karakter yang ditujukan untuk masyarakat, bangsa, negara dan dunia international atau global, terdiri dari nilai budi pekerti welas asih, berjiwa pemimpin, tanggung jawab, dan bijaksana. Bawana langgeng dimaknai sikap, perilaku, dan karakter yang ditujukan untuk alam akhirat, terdiri dari nilai religius.

Keterkaitan karakter dengan tema konseling yang lain ditujukan agar bisa menemukan bagian-bagian penting di dalam tema lain konseling yang bisa dikorelasikan dengan karakter. Bimbingan dan konseling di sekolah dilaksanakan secara kolaboratif dengan para guru mata pelajaran, tenaga kependidikan, maupun orang tua dan pemangku kepentingan lainnya. Keutuhan layanan bimbingan dan konseling diwujudkan dalam landasan filosofis bimbingan dan konseling yang memandirikan, berorientasi perkembangan, dengan komponenkomponen program yang mencakup layanan dasar, layanan responsif, layanan peminatan dan perencanaan individual, dan dukungan sistem.

\section{REFERENSI}

Al-Quran al Karim. 2008. Departemen Agama: Jakarta.

Arfiyah, Nur. 2014. Ekologi Berwawasan Gender dalam Perspektif Al-Qur'an. Jakarta: Mizan Book.

Berry, John W., dkk. 2002. CrossCultural Psychology, Second Edition. New York: Cambridge University Press.

Edgerton, Robert B. 2011. Kebangkitan

Peran Budaya: Bagaimana Nilai-nilai Membentuk

Kemajuan Manusia. Jakarta: Pustaka LP3ES.

Endraswara, Suwardi. 2016. Метауи Hayuning Bawana: Laku Menuju Keselamatan dan Kebahagiaan Hidup Orang Jawa. Jakarta: Narasi.

Gusria, W. 2015. Karakter Individu Mandiri dalam Karya Buya Hamka dan Kontribusinya Bagi Bimbingan Berbasis Budaya. Tesis. Universitas Negeri Malang.

Indiarti, Wiwin. 2017. Character Builder Values in The Origin of 
Watu Dodol Folktale. Jentera: Jurnal Kajian Sastra. Vol. 6.

Kemendikbud RI. 2017. Infografis Gerakan Penguatan Pendidikan Karakter. Jakarta.

Lickona, T. 1991. Educating for Character: Mendidik untuk Membentuk Karakter, Edisi Terjemahan. Jakarta: BumiAksara.

Mappiare-AT., A. (2017). Meramu Model Konseling Berbasis Budaya Nusantara: KIPAS (Konseling Intensif Progresif Adaptif Struktur). Malang: Universitas Negeri Malang.

Nugroho,S.S., $\quad$ Elviandri. 2018. Memayu Hayuning Bawana: Melacak Spiritualitas Transendensi Hukum Pengelolaan Sumber Daya Alam berbasis Kearifan Masyarakat Jawa. Prosiding Seminar Nasional \& Call for Papers Hukum Transendental. Surakarta: UMS.

Nurgiyantoro, Burhan. 2000. Teori Pengkajian Fiksi. Yogyakarta: GadjahMada University Press.

Peterson, C., \& Seligman, Martin. 2004. Character Strengths and Virtues: a Handbook and Classification. New York: Oxford University Press.

Pusat Kurikulum dan Perbukuan, 2011. Panduan Pelaksanaan Pendidikan Karakter. Jakarta: Badan Penelitian dan Pengembangan Kemdiknas.

Soeyono. 2018. Ki Ageng Minak Sopal. Arsip. Perpustakaan Daerah Kabupaten Trenggalek.

Soyomukti, N, dkk. 2016. Peta Budaya Trenggalek. Trenggalek: Dinas
Pariwisata, Budaya, Pemuda, dan Olahraga Kabupaten Trenggalek dan Dewan Kesenian Trenggalek.

Syarief, Iriana, Y. 2015. Peranan Museum dalam Perspektif Pendidikan Nilai-Nilai Luhur Budaya dan Sejarah.Yogyakarta: Aswaja Pressindo.

Wilis, Abdul Hamid. 2005. Sejarah Masjid Agung "Baiturrahman" Kabupaten Trenggalek. Dinas Perpustakaan dan Arsip Kabupaten Trenggalek. 